\title{
THYROXINE-BINDING BY SERUM AND URINE PROTEINS IN NEPHROSIS. QUALITATIVE ASPECTS ${ }^{1}$
}

\author{
By JACOB ROBBINS, J. E. RALL, AND MARY L. PETERMANN 2 \\ (From the National Institute of Arthritis and Metabolic Diseases, National Institutes of Health, \\ Bethesda, Maryland, and The Sloan-Kettering Institute for Cancer Research, \\ New York, N. Y.)
}

(Submitted for publication April 1, 1957 ; accepted May 9, 1957)

The occurrence of hypercholesterolemia, lowered basal metabolic rate and depressed serum proteinbound iodine in the nephrotic syndrome has directed attention to the thyroid gland in this disorder. Although hypothyroidism has been suspected, these patients are usually considered, on clinical grounds, to be euthyroid, and they fail to respond in a specific manner to even large doses of thyroid hormone (1-3). Since the thyroid gland itself appears to be functioning normally, or even excessively, with respect to iodine accumulation (4), and responds in a normal fashion to thyrotropin and exogenous thyroxine (5), possible disorders in the peripheral metabolism of thyroid hormone have been investigated. Recant and Riggs (5) have suggested that the loss of hormonal iodine in the urine, although considerable, is insufficient to explain the low serum iodine concentration. These investigators demonstrated a normal degradation rate for exogenous thyroxine, whereas Rasmussen (6) found a lower than normal amount degraded each day.

Inasmuch as the circulating thyroid hormone is almost entirely bound to serum protein (7), and since the protein components of serum are extensively altered in nephrosis, a possible defect in this aspect of thyroid physiology has been suspected (5). A preliminary report from our laboratory (8), as well as one by Recant (9), has suggested the presence of a qualitatively abnormal thyroxine-protein complex in nephrotic serum. The data presented in this report, however, indicate that in the nephrotic state, the serum proteins which interact with thyroxine are normal from a physical standpoint.

1 Presented in part at the Laurentian Hormone Conference, Mont Tremblant, Canada, 1956.

2 Supported by a grant from the National Cancer Institute of the United States Public Health Service, No. C-471.

\section{MATERIALS AND METHODS}

Serum was obtained in the fasting state from 11 patients with the nephrotic syndrome. ${ }^{3}$ Urine was obtained from two patients. Clinical and laboratory data for these patients are listed in Table I.

Mixtures of serum (or concentrated urine, cf. below) and labeled L-thyroxine 4 were prepared by adding serum to the appropriate quantity of thyroxine previously dried in vacuo (10), and were equilibrated for at least 15 hours at $4^{\circ} \mathrm{C}$. Radiochemical purity was assessed by chromatography. The thyroxine was repurified, when necessary, to a purity of 90 per cent or greater before addition of serum (11). The final concentration of thyroxine was determined by iodine analysis of the serum (or urine) and of the thyroxine solution, corrected for losses during preparation of the mixture. Iodine analyses were performed by modification of the Barker (12) or Zak, Willard, Myers, and Boyle (13) ${ }^{5}$ procedures. A total of 52 serum mixtures and 9 urine mixtures were prepared, in which the concentration of added thyroxine varied from 0.009 to $6.3 \mu \mathrm{g}$. per $\mathrm{ml}$.

Zone electrophoresis in horizontally suspended paper strips was carried out by the conventional or reverseflow technique (11) in barbital buffer, $\mathrm{pH} 8.6$, ionic strength 0.1 . Radioactivity on the paper strips was measured with a continuously-recording, counting rate meter and an end-window Geiger-Mueller tube. The width of the counting aperture was $1 / 8$ inch or $1 / 4$ inch.

Moving boundary electrophoresis in acetate-chloride buffer at $\mathrm{pH} 4.5$ was carried out as described earlier (14), except that a lower voltage (about 4 volts per $\mathrm{cm}$.) and a longer time (about 8 hours) were used to avoid convective disturbances in the lipoprotein boundaries. Ultracentrifugation, employing a partition cell, was performed according to techniques reported elsewhere (15).

In one patient (Case No. 7), $22 \mu \mathrm{g}$. of L-thyroxine labeled with $1.0 \mathrm{mc}$. of $\mathrm{I}^{131}$ and dissolved in 50 per cent

\footnotetext{
3 These sera were generously supplied by Dr. Lee Farr from patients hospitalized at the Brookhaven National Laboratory, Upton, New York, and by Drs. Hans Keitel, James Baxter and Howard Goodman from patients in the National Heart Institute, National Institutes of Health, Bethesda, Maryland.

${ }^{4}$ L-thyroxine labeled with $\mathrm{I}^{131}$ was obtained from Abbott Laboratories, Oak Ridge, Tennessee.

5 Performed by J. Benotti, Boston Medical Laboratory. Boston, Mass.
} 
TABLE I

Clinical and laboratory data on patients with the nephrotic syndrome

\begin{tabular}{|c|c|c|c|c|c|c|c|c|}
\hline \multirow[b]{2}{*}{$\begin{array}{l}\text { Case } \\
\text { no. }\end{array}$} & \multirow[b]{2}{*}{ Age } & \multirow[b]{2}{*}{ Sex } & \multirow[b]{2}{*}{ Diagnosis } & \multirow[b]{2}{*}{$\underset{\mathbf{N}}{\text { Blood }}$} & \multicolumn{4}{|c|}{ Serum levels } \\
\hline & & & & & $\begin{array}{l}\text { Total } \\
\text { protein }\end{array}$ & Albumin & Cholesterol & $\begin{array}{c}\text { Protein- } \\
\text { bound } \\
\text { iodine }\end{array}$ \\
\hline & yrs. & & & $m g . \%$ & $\mathrm{Gm} . \%$ & Gm. \% & $m g . \%$ & $\mu g . \%$ \\
\hline 1 & 4 & $\mathbf{M}$ & Idiopathic & 25 & 5.0 & 1.1 & & 0.4 \\
\hline 2 & 4 & $\mathbf{M}$ & Idiopathic & 10 & 4.5 & 2.0 & 491 & $5.4 \dagger$ \\
\hline$\overline{3}$ & 19 & $\mathbf{M}$ & Hodgkin's disease & 6.3 & 6.1 & & 535 & 1.5 \\
\hline${ }_{\mathrm{B}}^{4 \mathrm{~A}^{*}}$ & 3 & $\mathrm{~F}$ & Idiopathic & 5.7 & 4.3 & 1.2 & 959 & 1.7 \\
\hline $5^{B}$ & 6 & $F$ & Idiopathic & 200 & $\begin{array}{l}4.0 \\
3.9\end{array}$ & $\begin{array}{l}0.9 \\
2.1\end{array}$ & $\begin{array}{l}785 \\
676\end{array}$ & \\
\hline 6 & 6 & $\mathrm{~F}$ & Idiopathic & 20 & 4.1 & 0.6 & 1,522 & 1.2 \\
\hline 7 & 23 & $\mathrm{~F}$ & Disseminated lupus & 36 & 3.6 & 1.2 & 510 & 5.2 \\
\hline $8 A^{*}$ & 54 & $\mathbf{M}$ & Primary amyloidosis & 38 & 4.1 & 0.8 & 807 & 2.1 \\
\hline B & & & & 39 & 4.0 & 2.1 & 595 & 1.4 \\
\hline 9 & 7 & $\mathbf{M}$ & Idiopathic $\ddagger$ & 16 & 5.4 & 1.7 & 814 & 3.2 \\
\hline 10 & 35 & $\mathrm{~F}$ & Disseminated lupus & 65 & 2.7 & 0.4 & 493 & 2.2 \\
\hline 11 & 7 & $\mathrm{~F}$ & Idiopathic & 31 & 3.9 & 0.4 & 1,085 & 0.1 \\
\hline
\end{tabular}

* "A" and "B" refer to sera obtained at different times from these patients.

$\dagger$ Receiving Lugol's solution.

$\ddagger$ Receiving metacorten.

propylene glycol was injected intravenously. Serum and urine specimens were collected at intervals following the injection. In addition to electrophoretic analysis, the urinary radioiodine was subjected to analysis by the following procedures in a manner similar to that employed with serum: paper chromatography with n-butanol: dioxane $(4: 1)$ equilibrated with $2 \mathrm{~N} \mathrm{NH}_{4} \mathrm{OH}$, extraction with n-butanol (16), salting out with phosphate buffer (17), and dialysis against large'volumes of 0.85 per cent $\mathrm{NaCl}$. Prior to electrophoresis, the urinary proteins were concentrated three- to six-fold by dialysis against a 25 per cent solution of polyvinyl pyrrolidone in barbital buffer. This patient's serum and urine were also used for in vitro thyroxine experiments.

\section{RESULTS AND DISCUSSION}

The results with the thyroxine-serum mixtures may be considered in two categories: those in which most of the thyroxine is associated with the specific thyroxine-binding alpha globulin (TBP), and those in which TBP is saturated, so that secondary thyroxine-binding proteins may be examined. Although it will be evident that these categories overlap, they are, for convenience, considered separately in parts I and II of this section ( $c f$. comments).

\section{Low thyroxine concentration in serum}

Mixtures of labeled L-thyroxine and nephrotic serum were prepared, in which the concentration of added thyroxine was from 0.009 to $0.1 \mu \mathrm{g}$. per $\mathrm{ml}$. and in which the total thyroxine concentration (i.e., added thyroxine plus endogenous thyroxine ${ }^{6}$ ) ranged from 0.015 to $0.18 \mu \mathrm{g}$. per $\mathrm{ml}$. The radioactive thyroxine-protein complex was then characterized by zone electrophoresis at $\mathrm{pH}$ 8.6, moving boundary electrophoresis at $\mathrm{pH} 4.5$, and ultracentrifugation.

\section{A. Electrophoresis at $p H 8.6$}

The findings presented in Figure 1 are illustrative of the results in 10 nephrotic subjects. In both conventional and reverse-flow zone electrophoresis, a radioiodine peak which did not coincide exactly with any of the major protein bands accounted for the major portion of the radioiodine in the serum. (A similarly located radioiodine peak was presented in the sera of the remaining patient [Case No. 11], but less than half of the radioiodine was in this zone at the lowest thyroxine level studied, $0.14 \mu \mathrm{g}$. per ml.) This peak had a mobility which was of the order of that of the alpha globulins of normal serum. On the basis of direct comparison between nephrotic and normal sera containing thyroxine- $\mathrm{I}^{131}$ and run simultaneously, the electrophoretic mobility of the thyroxine-

6 For the purposes of the calculation, the serum iodine was assumed to consist entirely of thyroxine. 
binding protein (TBP) appeared to be the same in both-i.e., intermediate between the alpha-1 and alpha-2 globulins (6, 18-20).

The serum mixtures also contained thyroxine in the albumin zone. In conventional zone electrophoresis this comprised from 1 to 8 per cent of the total serum thyroxine, whereas in the reverseflow experiments it comprised from 18 to 33 per cent (see part II). In addition, all of the sera contained a third radioiodine peak which moved just ahead of, and was poorly separated from the albumin peak (Figure 1). In most sera, this component was rather small ( 2 to 7 per cent of total serum thyroxine) and was similar to the "prealbumin" radioiodine component noted in normal serum (10). In three subjects (Case Nos. 8B, 9, and 10), however, this component was more prominent, particularly in the reverse-flow experiments, and comprised approximately 10 to 25 per cent of the total serum radioiodine. The pattern in Figure $1 \mathrm{C}$. contained 17 per cent of its radioiodine in this component. It is uncertain whether or not this "pre-albumin" component is the same as that which is found in cerebrospinal fluid $(21,22)$, where it has been shown to form a complex with thyroxine $(16,23)$. The pre-albumin component in nephrotic serum was usually less clearly separated from albumin than in cerebrospinal fluid, and its significance is not clear.

The variable quantities of radioiodine which were deposited between the TBP area and the point of application in conventional electrophoresis (and which were often more striking than illustrated in Figure 1) were absent from the reverse-flow experiments, and appeared to be an artifact (see part II). The findings in the patient injected intravenously with labeled L-thyroxine (Case No. 7) were similar to those presented in Figure 1, except that there was less radioactivity in the pre-albumin zone.

\section{B. Electrophoresis at $p H 4.5$}

A mixture of labeled L-thyroxine and serum from one patient (Case No. 4B), containing a total of $0.047 \mu \mathrm{g}$. of thyroxine per ml., was subjected to moving boundary electrophoresis at $\mathrm{pH} 4.5$. The results are presented in Figure 2, and may be compared with those for normal sera published earlier (14). The small protein peak in fractions 2 and

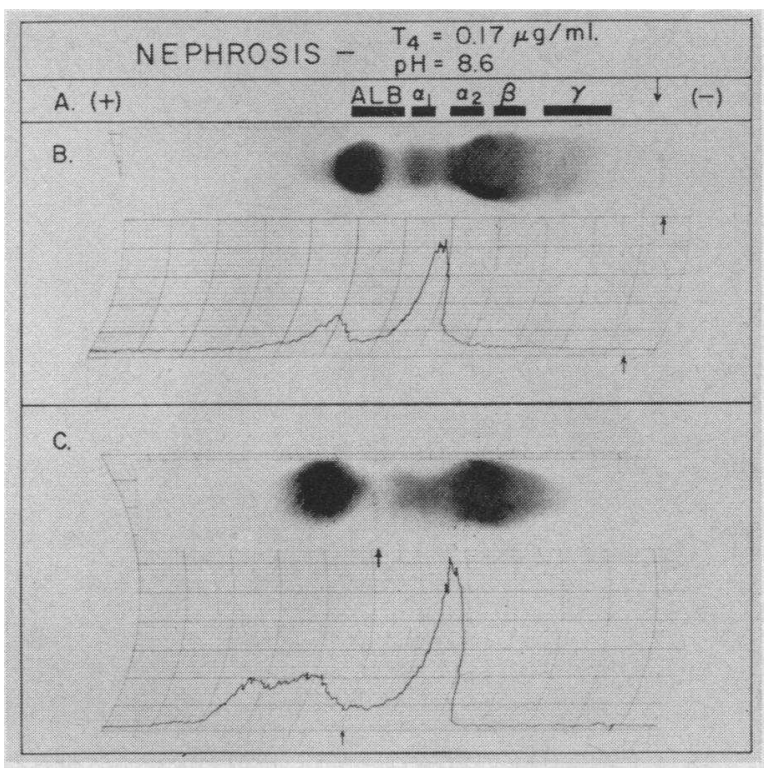

Fig. 1: Zone Electrophoresis of a Mixture of Labeled L-Thyroxine and Serum From Case No. 8B, Low Thyroxine Concentration

A. and B., conventional method. C., reverse-flow method. In B. and C., the paper strips, stained with bromphenol blue, are aligned with records of their radioactivity. The arrows indicate the points at which serum was applied. The distances between base-line radioactivity and the bottom lines of the charts represent background counting rates. The bars in A. indicate the location of protein zones in a normal serum run simultaneously with $B$. $T_{4}=$ total serum thyroxine.

3 contained a major radioiodine component and had the highest $\mathrm{I}^{\mathbf{1 3 1}}$ : protein ratio. Inasmuch as the location of albumin in the schlieren pattern could not be determined by inspection, as may be done in the case of normal serum, the fractions denoted in Figure 2 were concentrated (by dialysis against 25 per 'cent polyvinyl pyrrolidone) and examined by zone electrophoresis at $\mathrm{pH}$ 8.6. The protein patterns for fractions 2 and 4 are presented in Figure 2. Whereas the latter contained a protein component with the mobility of albumin, fraction 2 contained a single visible component, the mobility of which was comparable to that of alpha-2 globulin. Since the most acid fraction of albumin is isoelectric at about $\mathrm{pH} 4.5$, it may be concluded that TBP in this nephrotic serum had an isoelectric point slightly lower than $\mathrm{pH} 4.5$. The behavior of this protein was, therefore, indistinguishable from that of TBP in normal sera by electrophoresis at both alkaline and acid $\mathrm{pH}$. 


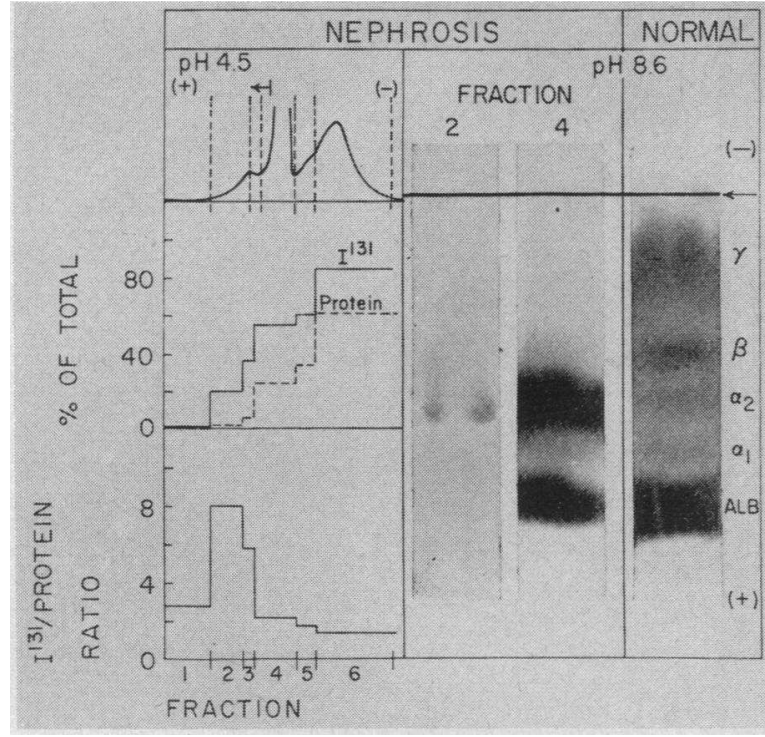

Fig. 2. Moving Boundary Electrophoresis of a Mixture of Labeled L-Thyroxine and Serum From Case No. 4B, Total Thyroxine Concentration $=0.047$ $\mu$ G. PER mL. (The TBP Area in Conventional Zone Electrophoresis at pH 8.6 Contained 71 Per Cent of THE THYROXINE)

Top left: tracing of schlieren diagram in acetatechloride buffer. The top of the largest peak is cut off. The vertical line at the top indicates the starting boundary, and the arrow points in the ascending direction. The broken lines indicate the fractions taken for analysis. Middle left: radioiodine and protein in the fractions, the latter measured by ultraviolet absorption at $275 \mathrm{~m} \mu$. Bottom left: radioiodine-protein ratios in the fractions. Right: zone electrophoretic patterns in barbital buffer of concentrated fractions 2 and 4 compared with that of normal serum. The strips are stained with bromphenol blue.

\section{Ultracentrifugation}

The thyroxine-protein complex in two sera, (Case Nos. 1 and 4B) was studied in the ultracentrifuge partition cell. In one (Case No. 1), the serum was first subjected to centrifugation in the preparative ultracentrifuge (untreated whole serum at $105,000 \times \mathrm{G}$ for $2 \frac{1}{2}$ hours at $8^{\circ} \mathrm{C}$.) and the low density lipids which floated to the top were removed. This low density material contained no thyroxine, and zone electrophoresis of the remaining serum revealed a radioactivity pattern identical with that in whole serum.

The results of the partition cell experiments are presented in Figure 3 and Table IIA. The rate of disappearance of radioiodine from the top compartment of the cell (Figure 3) was similar to

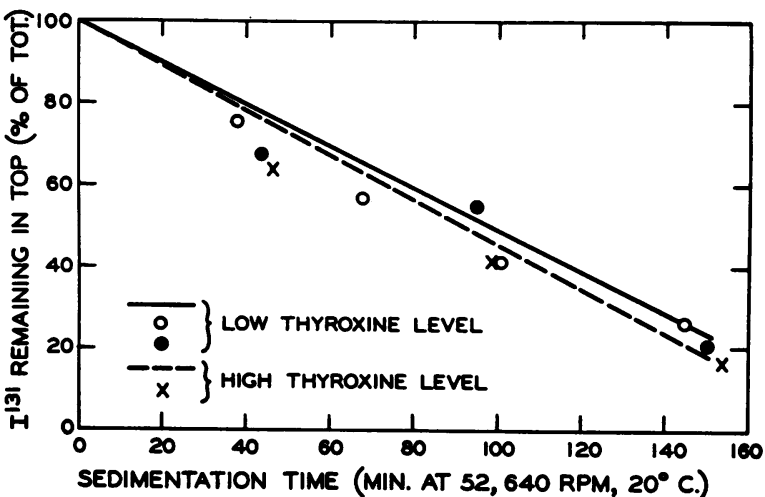

Fig. 3. Sedimentation in the Ultracentrifuge Partition Cell of Mixtures of Labeled L-Thyroxine and SERUM

The lines are theoretical curves, calculated from the sedimentation equations, where $s_{20}$ for TBP in diluted serum $=3.22 \mathrm{~S}, \mathrm{~s}_{20}$ for albumin $=4.05 \mathrm{~S}$, and $\mathrm{s}_{20}$ for iodide $=0$. The symbols represent experimental data, each point being the result of a separate experiment. Pertinent data are as follows:

\begin{tabular}{|c|c|c|c|c|c|}
\hline Symbol & $\begin{array}{c}\text { Case } \\
\text { no. }\end{array}$ & $\begin{array}{c}\text { Total } \\
\text { thyroxine }\end{array}$ & TBP & Albumin & Iodide \\
\hline & & $\mu g . / m l$. & & $\begin{array}{c}\text { total } I^{181} \\
\%\end{array}$ & \\
\hline & & & 70 & 25 & 5 \\
\hline 0 & $\begin{array}{l}1 \\
4 \mathrm{~B}\end{array}$ & $\begin{array}{l}0.044 \\
0.047\end{array}$ & $\begin{array}{l}66 \\
71\end{array}$ & $\begin{array}{l}29 \\
24\end{array}$ & $\begin{array}{l}5 \\
5\end{array}$ \\
\hline $\mathrm{X}$ & 1 & 0.28 & $\begin{array}{l}40 \\
39\end{array}$ & $\begin{array}{l}55 \\
56\end{array}$ & $\begin{array}{l}5 \\
5\end{array}$ \\
\hline
\end{tabular}

Since the proportion of $\mathrm{I}^{131}$ with TBP and albumin were determined by conventional zone electrophoresis, it is probable, especially at the high thyroxine level, that TBP was overestimated and albumin underestimated. This error does not significantly affect the results of the ultracentrifuge experiments. Any radioiodine present in the alpha-2, beta, or gamma globulin areas was considered to be derived from thyroxine associated with albumin. In the instance of Case No. 1, $0.28 \mu \mathrm{g}$. per ml., the "albumin" radioiodine was composed of 32 per cent of total $\mathrm{I}^{131}$ in the alpha-2 globulin zone, 16 per cent in the beta and gamma globulin zones, and only 8 per cent in the albumin zone. Iodide- $\mathrm{I}^{131}$ was determined by chromotography.

that expected with normal serum containing a similar distribution of thyroxine between TBP, albumin and iodide. The sedimentation coefficient of TBP (Table IIA) was calculated from the partition cell equations (15) by using the value $\mathrm{s}_{20, \mathrm{w}}=4.2 \mathrm{~S}^{7}$ for albumin and the distributions of radioiodine between TBP, albumin and iodide as

\footnotetext{
${ }^{7} \mathrm{~S}_{20, \mathrm{w}}=\mathrm{s}_{20} \times 1.037$.
} 
given in the legend to Figure 3. The drift toward a lower sedimentation coefficient with increasing centrifugation time suggests that these sera may have contained a small amount of a rapidly sedimenting, radioiodine component.

One of these sera (Case No. 1) was examined optically in the analytical ultracentrifuge and was found to contain a rapidly sedimenting component $\left(\mathrm{s}_{20, \mathrm{w}}=17.1 \mathrm{~S}\right)$ which contained 16.5 per cent of the total protein. When serum proteins from this patient were separated by moving boundary electrophoresis in barbital buffer, $\mathrm{pH}$ 8.6, and samples removed from the descending limb of the cell examined in the analytical ultracentrifuge, the rapidly sedimenting component was found to be associated with the large alpha- 2 globulin peak. This finding is consistent with recent studies by Brown and co-workers $(24,25)$ who have shown that a macroglobulin, which is probably an alpha glycoprotein, is present in normal serum and is markedly increased in nephrosis. The association of approximately 5 per cent of the serum thyroxine with such a macroglobulin could produce the drift seen in Table II. The sedimentation coefficients calculated for TBP at the longer time intervals ( $>67$ minutes), however, would not be affected by the presence of such a rapidly sedi-

TABLE II

Sedimentation coeflcients calculated from ultracentrifuge partition cell experiments (cf. legend to Figure 3 for other pertinent data)

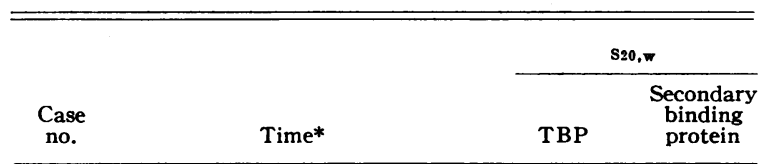

A. Low thyroxine concentration

\begin{tabular}{lcc}
\hline & $\min$. & Svedbergs \\
1 & 43.6 & 5.5 \\
& 95.6 & 3.2 \\
$4 \mathrm{~B}$ & 150.3 & 3.9 \\
& 37.7 & 4.6 \\
& 67.7 & 4.4 \\
& 100.4 & 4.1 \\
& 144.8 & 3.4 \\
\end{tabular}

B. High thyroxine concentration

\begin{tabular}{ccc}
\hline & min. & Svedbergs \\
1 & 45.8 & 6.5 \\
& 99.5 & 4.9 \\
& 153.5 & 4.5 \\
\hline
\end{tabular}

* Sedimentation time at $52,640 \mathrm{rpm}, 20^{\circ} \mathrm{C}$. menting component, and, therefore, may represent the true sedimentation rate for TBP in nephrosis. These values for $s_{\mathbf{2 0}, \mathbf{w}}$ have a mean of 3.6 $\mathrm{S}$, which is comparable within experimental error to the value of $3.3 \mathrm{~S}$ for TBP in normal serum (15). The possible presence of a prealbumin thyroxine-binding component in these sera (see above) was not considered in the calculations. This omission may not introduce a significant error, inasmuch as the pre-albumin component present in normal serum has a sedimentation rate of the order of serum albumin (26).

\section{High thyroxine concentrations in serum}

Mixtures of labeled L-thyroxine and serum were prepared which contained from 0.2 to $6.3 \mu \mathrm{g}$. of thyroxine per ml., amounts sufficient to saturate the thyroxine-binding sites on TBP.

\section{A. Electrophoresis at $p H 8.6$}

The electrophoretic distribution of thyroxine presented in Figure 4A. is representative of the findings in all sera examined at high thyroxine

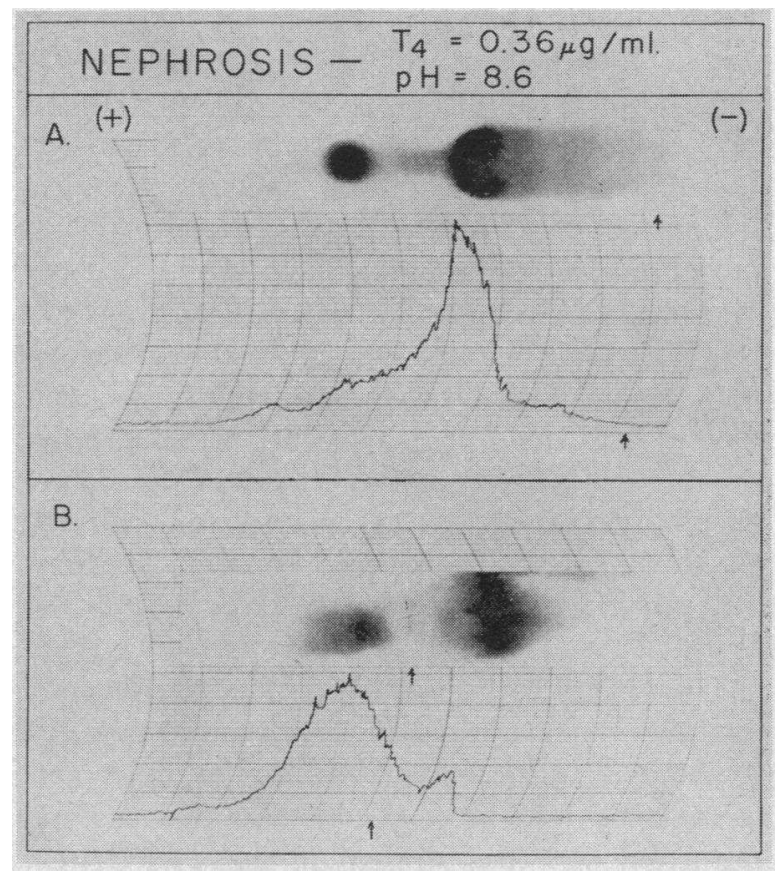

Fig. 4. Zone Electrophoresis of a Mixture of Labeled L-Thyroxine and Serum From Case No. 11, High Thyroxine Concentration

A., conventional method. B., reverse-flow method. (Cf. legend to Figure 1.) 


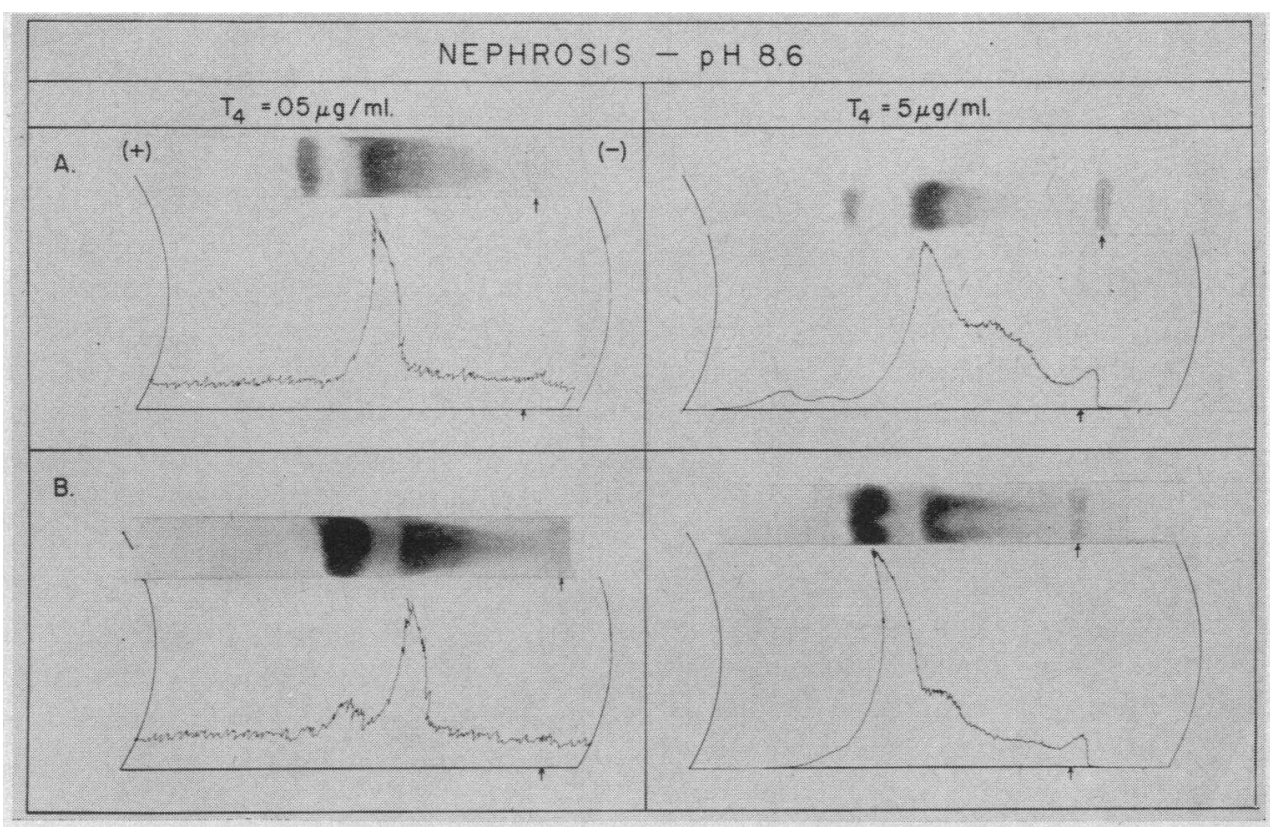

Fig. 5. Zone Electrophoresis (Conventional Method) of Mixtures of Labeled L-Thyroxine and Serum From Case No. 6 at Low and High Thyroxine Concentrations

A., no addition. B., human serum albumin added $(3.5 \mathrm{Gm}$. per $100 \mathrm{ml}$. of serum). ( $C f$. legend to Figure 1.)

concentrations by the conventional technique. A large, broad peak of radioactivity was always found in the region of the dense, abnormal protein zone which had a mobility close to alpha- 2 globulin. Although this radiothyroxine peak sometimes coincided with the protein zone, it not infrequently moved somewhat slower or, as in Figure 4A., somewhat faster. Its mobility was distinct from that of TBP. The proportion of thyroxine associated with this zone appeared to vary with the albumin content of the serum. When the serum albumin was high, less thyroxine was found in the alpha-2 globulin region and more in albumin. Variable quantities of radioiodine were present between the point of application and the major peak as well as in the pre-albumin region (see part I).

The pattern in Figure 4B. on the other hand, is typical of the results obtained with the reverse flow technique. In these experiments, the major zone of radioactivity was in the albumin area, a small thyroxine peak was present in the TBP region, and there was no radioactivity in the region of the globulins with mobilities slower than TBP. It is evident from a comparison of Figures 4A. and 4B. that the large alpha globulin component in Fig- ure 4A. could represent an artifact in the conventional electrophoresis procedure. A similar, but quantitatively smaller, artifact has been described in normal serum (11), and appears to be the result of adsorption and dissociation of the thyroxine-albumin complex during migration through the paper strip. In the nephrotic sera, this artifact appeared to be accentuated as a result of the lower albumin concentrations. Figure 5 illustrates the effect of adding human serum albumin ${ }^{8}$ to nephrotic serum. The artifact could be reduced by this addition.

That the large magnitude of this artifact is not a characteristic only of nephrotic sera is demonstrated in Figure 6. In this experiment, a mixture of a normal serum and thyroxine, in which the thyroxine-sites on TBP were saturated, was applied to the paper strips in varying amounts. When the volume was small, and the conventional electrophoretic technique was employed, the albumin-bound thyroxine was deposited largely in

\footnotetext{
${ }^{8}$ Fraction $\mathrm{V}$ of human plasma, obtained through the courtesy of Dr. S. T. Gibson and Dr. J. N. Ashworth of the American National Red Cross and E. R. Squibb and Sons, respectively.
} 


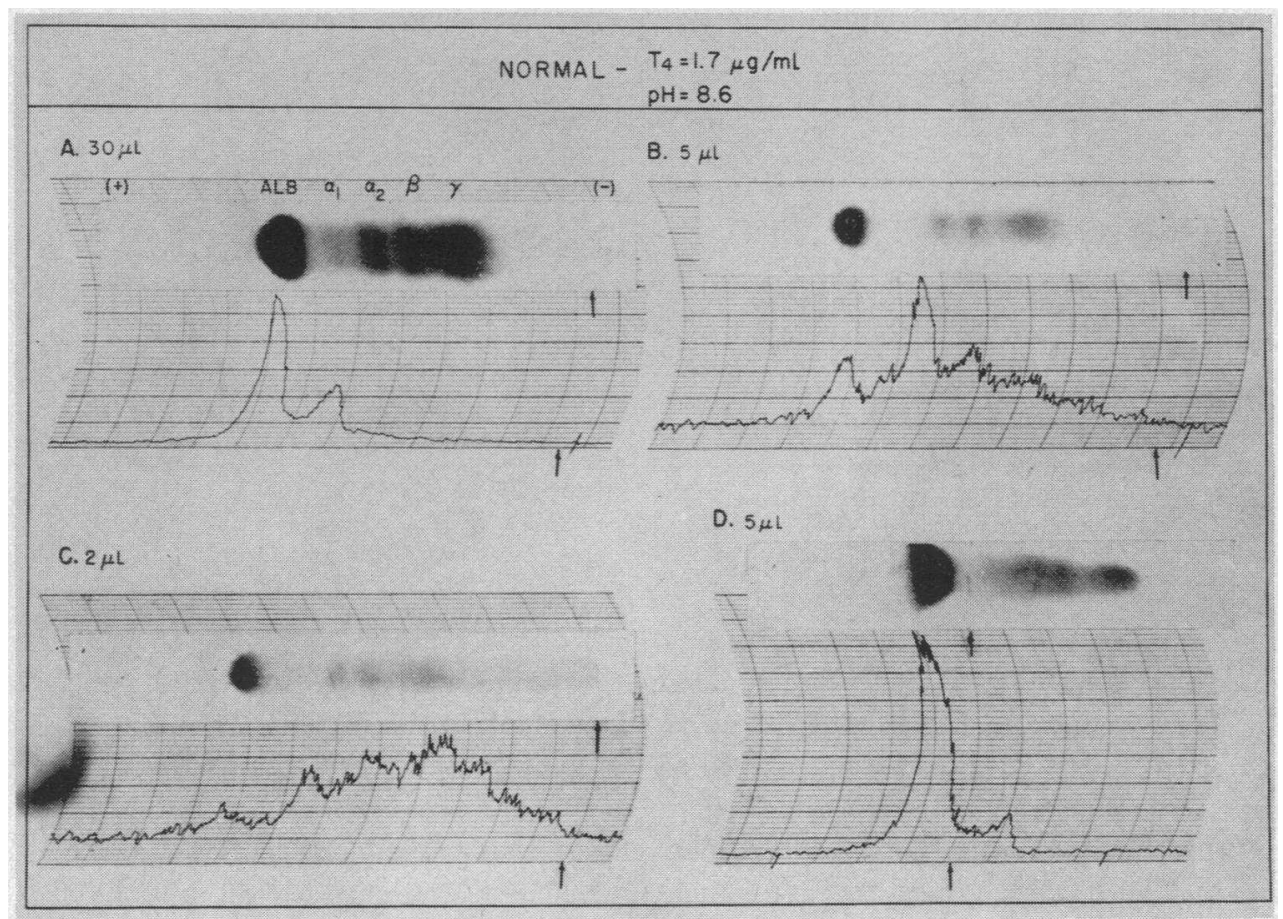

Fig. 6. Zone Electrophoresis of a Single Mixture of Labeled L-Thyroxine and NoRmal Serum

A., B., C., conventional method. D., reverse-flow method. The volumes indicate the quantity of serum applied to the paper in each instance. The distribution of $I^{131}$ shown in $D$. was the same at all volumes with the reverse-flow method. (Cf. legend to Figure 1.)

the serum globulin regions. This was apparently a consequence of the reduced amount of albumin on the strip. The failure to find a single large thyroxine peak in the alpha- 2 globulin region in this experiment, compared to nephrotic sera at high thyroxine levels, may be due to the relative difference in globulin concentrations in the normal and nephrotic sera. For example, the presence of a globulin in relatively large amount might minimize the adsorption of albumin-thyroxine on the paper up to the point where this globulin itself is deposited.

\section{B. Ultracentrifugation}

The possibility that not all the thyroxine at these high concentrations was associated with protein was examined in two sera (Case Nos. 1 and $4 \mathrm{~A}$ ), which contained 1.5 and $6.3 \mu \mathrm{g}$. of thyroxine per $\mathrm{ml}$., respectively. The mixtures were subjected to ultracentrifugation in the partition cell at $52,640 \mathrm{rpm}$ for 4 hours. The proportions of thyroxine remaining in the top compartment were
11 per cent and 8 per cent, respectively, indicating that most of the thyroxine was bound to protein even at these high concentrations. In addition, it may be calculated from equations for the interaction of thyroxine with serum protein (16) that even with an albumin level of $1.0 \mathrm{Gm}$. per cent and $10 \mu \mathrm{g}$. of thyroxine per ml., no more than about 2 per cent of the thyroxine would be unbound.

In a single experiment (Case No. 1) similar to that at a low thyroxine level, serum was subjected to ultracentrifugation in the preparative ultracentrifuge at $105,000 \times \mathrm{G}$ for $2 \frac{1}{2}$ hours. It was found that the serum thyroxine was not associated with the low density lipids.

In one instance (Case No. 1), a thyroxine-serum mixture containing $0.28 \mu \mathrm{g}$. of thyroxine per $\mathrm{ml}$. was subjected to ultracentrifugation in the partition cell. The thyroxine-sites on TBP were saturated, and zone electrophoresis by the conventional method revealed only 39 per cent of the radioiodine in the TBP region (see legend to Figure 3 ). The results are presented in Figure 3 and Table IIB. 
Urine radioiodine analyses after intravenous thyroxine- $I^{131}$ in nephrosis *

\begin{tabular}{|c|c|c|c|c|c|c|}
\hline \multirow{3}{*}{$\begin{array}{c}\text { Interval } \\
\text { after dose }\end{array}$} & & & & \multicolumn{2}{|c|}{ Solubility in } & \multirow[b]{3}{*}{ Dialyzability } \\
\hline & \multicolumn{3}{|c|}{ Chromotography $\dagger$} & \multirow{2}{*}{$\begin{array}{c}3.15 \mathrm{M} \\
\text { phosphate } \\
\text { buffer } \neq\end{array}$} & \multirow{2}{*}{$\begin{array}{c}\text { n-butanol } \\
\text { (washed with } \\
4 \mathrm{~N} \mathrm{NaOH}- \\
5 \% \mathrm{Naz} \text { ) }\end{array}$} & \\
\hline & Thyroxine & Iodide & Origin & & & \\
\hline $\begin{array}{c}0-6 \text { hrs. } \\
6-12 \text { hrs. } \\
12-24 \text { hrs. } \\
1-2 \text { days } \\
2-3 \text { days }\end{array}$ & $\begin{array}{l}88 \\
96 \\
91 \\
78 \\
78\end{array}$ & $\begin{array}{r}10 \\
4 \\
9 \\
13 \\
19\end{array}$ & $\begin{array}{l}3 \\
0 \\
0 \\
9 \\
4\end{array}$ & $\begin{array}{l}10 \\
10 \\
17 \\
15\end{array}$ & $\begin{array}{l}80 \\
83 \\
81 \\
72 \\
68\end{array}$ & $\begin{array}{r}7 \\
12 \\
11 \\
15 \\
24\end{array}$ \\
\hline
\end{tabular}

* All values are per cent of the total $I^{131}$ in urine.

$\dagger \mathrm{n}$-butanol: dioxane: ammonia.

$\ddagger$ Equimolecular $\mathrm{KH}_{2} \mathrm{PO}_{4}-\mathrm{K}_{2} \mathrm{HPO}_{4}$.

It may be seen in Figure 3 that the rate of disappearance of radioiodine from the upper compartment of the cell was not much different from the theoretical normal curve with a similar thyroxine distribution. This suggested that the sedimentation rate of the protein other than TBP which was interacting with thyroxine was not much different from that for TBP $\left(s_{20, w}=3.3 \mathrm{~S}\right)$ and albumin $\left(\mathrm{s}_{20, \mathrm{w}}=4.2 \mathrm{~S}\right)$. If it is assumed that this serum contained only two types of protein which could bind thyroxine, one of which was $\mathrm{TBP}$, the sedimentation coefficient of the second protein could be calculated from the sedimentation equations (15). The mean value obtained for the second protein was $\mathrm{s}_{20, \mathrm{w}}=4.7 \mathrm{~S}$, when the sedimentation time was longer than 67 minutes. This value is not significantly different from the sedimentation coefficient of serum albumin. The possible presence of a pre-albumin thyroxine component was again ignored in the calculations (see part IC).

\section{Interaction of thyroxine with urine proteins}

Urine collected from Patient No. 7 at varying intervals after the intravenous administration of radiothyroxine was analyzed by the procedures listed in Table III. Most of the radioiodine in these urine specimens was in the form of thyroxine bound to protein. It should be noted that this patient had uremia, and there were considerable losses of radioactivity in the feces and by emesis. The latter was shown by chromatography to be in the form of iodide.

The zone electrophoretic analysis of urine concentrated five-fold, presented in Figure 7, is typi- cal of the findings on all the specimens. Most of the radioactivity was in a zone which had a mobility intermediate between alpha-1 and alpha-2 globulin, and a very small amount was associated with albumin.

In two patients (Case Nos. 7 and 10), urine which was concentrated three-fold and which contained no endogenous radioiodine was mixed with labeled thyroxine so that the total thyroxine concentrations varied from 0.11 to $4.3 \mu \mathrm{g}$. per $\mathrm{ml}$. The electrophoretic distribution of thyroxine in the urine from Patient No. 7 at thyroxine concentrations lower than $0.2 \mu \mathrm{g}$. per ml. was similar to that illustrated in Figure 7 . At higher concentrations (analyzed by the reverse-flow method) less radioiodine was present in the "inter-alpha" zone, and correspondingly more in albumin.

In the case of Patient No. 10, however, thyroxine was found only in the albumin zone (in reverse-flow electrophoresis) at even the lowest thyroxine level $(0.11 \mu \mathrm{g}$. per $\mathrm{ml}$.). This patient's serum contained TBP with the characteristic "inter-alpha" mobility. The reason for the discrepancy between the findings in these two patients is not apparent.

\section{COMMENTS}

The results which have been described indicate that the proteins in serum which interact with thyroxine are, in all likelihood, the same in patients with nephrosis as in normal subjects. The presence of subtle differences, however, has not been eliminated by the rather gross methods employed. In addition, the tacit assumption that the thyroxine-binding alpha globulin, TBP, is a single 
protein species requires verification, inasmuch as this protein has not yet been isolated.

This report has not dealt with the possibility that quantitative differences in thyroxine-binding may exist. Preliminary data on this question (16) indicate that the thyroxine-binding capacity of TBP (which probably reflects the concentration of TBP) may be lower than normal in nephrosis. ${ }^{9}$ With a reduction in specific binding sites, it follows that the concentration of unbound, or free, thyroxine at any level of PBI would be higher than if TBP concentration were normal. Attempts at calculation of the free thyroxine concentration (16) suggest that this value in nephrosis may be normal or even elevated in the presence of a very low PBI. Since there is evidence suggesting that the physiological effects of thyroxine may be a function of the free rather than the total thyroxine (16), euthyroidism and a low PBI could thus coexist in nephrosis. Recant and Riggs (5) reasoned similarly on theoretical grounds. Other features of the complicated thyroid physiology in nephrosis have been discussed elsewhere $(5,6,16)$.

It should be pointed out that the thyroxine-binding capacity of TBP, which was quantitated in some of the patients in this study, varied from very low to normal values. This fact is responsible for the wide range of thyroxine concentrations which could be considered as "low thyroxine concentration" in part I of the section on results. The arbitrary division into "low" and "high" concentration groups was based on whether the major portion of the serum thyroxine was complexed with TBP or with the secondary binding protein. Since actual saturation of TBP with thyroxine is approached asymptotically $(11,16)$, the term "saturation" as used in this report is an approximation and is employed in a descriptive sense.

\section{SUM MARY}

Sera from 11 patients with the nephrotic syndrome were studied with regard to the nature of the proteins which interact with thyroxine. The proteins were labeled by the addition of radiothyroxine in vitro or, in one patient, by intra-

\footnotetext{
9 Earlier studies (8) which failed to demonstrate a depression of TBP were in error due to the artifact inherent in conventional zone electrnohoresis.
}

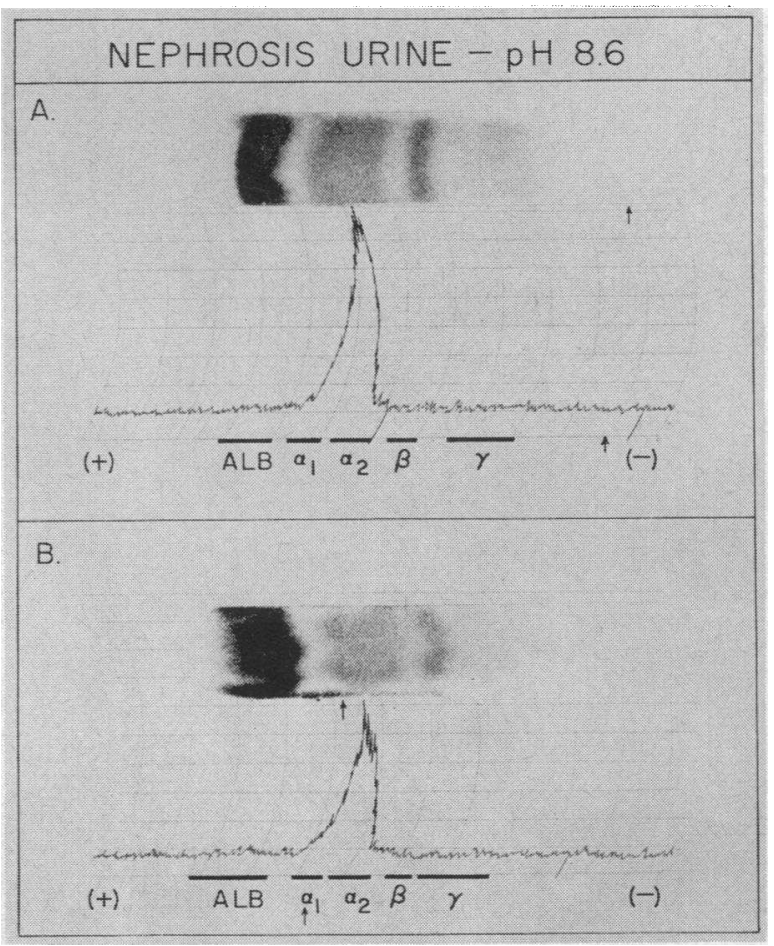

Fig. 7. Zone Electrophoresis of Urine, Concentrated Five-Fold, From Case No. 7, Collected BeTWEen 12 and 24 Hours Following Intravenous InJECTION OF LABELED L-THYROXINE

A., conventional method. B., reverse flow-method. (Cf. legend to Figure 1.)

venous injection. As in normal serum, thyroxine appeared to interact chiefly with two proteins: albumin and an alpha globulin (TBP). There was suggestive evidence that thyroxine interacted to a lesser degree with a third protein component having an electrophoretic mobility at $\mathrm{pH} 8.6$ slightly faster than albumin, and possibly with a fourth component characterized by a rapid sedimentation rate. TBP in the nephrotic sera appeared to be identical with normal TBP with respect to electrophoretic mobility at $\mathrm{pH} 8.6$ and $\mathrm{pH} 4.5$, and sedimentation rate in the ultracentrifuge.

At low thyroxine concentrations, the thyroxineTBP complex accounted for most of the serum thyroxine. At high thyroxine concentrations, TBP was saturated with thyroxine and the excess thyroxine became associated with albumin. In the presence of low serum albumin concentration, however, conventional zone electrophoresis in filter paper gave rise to an artifact due to adsorp- 
tion of albumin-bound thyroxine in the globulin zones.

The urine in one nephrotic patient was found to contain thyroxine in combination chiefly with TBP, and excess thyroxine added to this urine became associated with albumin.

\section{ACKNOWLEDGMENT}

The authors wish to thank Mrs. Mary G. Hamilton for performing the moving-boundary electrophoresis and the ultracentrifuge analyses. They are also indebted to Miss Dorothea Jermany and Miss Helen Hagopian for technical assistance.

\section{REFERENCES}

1. Epstein, A. A., Thyroid therapy and thyroid tolerance in chronic nephrosis. J. A. M. A., 1926, 87, 913.

2. Leiter, L., Nephrosis. Medicine, 1931, 10, 135.

3. Peters, J. P., and Man, E. B., The relation of albumin to precipitable iodine of serum. J. Clin. Invest., 1948, 27, 397.

4. Skanse, B., Radioactive iodine in the diagnosis of thyroid disease. Acta. med. Scandinav., 1949, Suppl., 235.

5. Recant, L., and Riggs, D. S., Thyroid function in nephrosis. J. Clin. Invest., 1952, 31, 789.

6. Rasmussen, H., Thyroxine metabolism in the nephrotic syndrome. J. Clin. Invest., 1956, 35, 792.

7. Trevorrow, V., Studies on the nature of the iodine in blood. J. Biol. Chem., 1939, 127, 737.

8. Robbins, J., Rall, J. E., and Petermann, M. L., Protein-binding of thyroxine in normal and nephrotic serum (abstract). J. Clin. Invest., 1954, 33, 959.

9. Recant, L., An abnormality in thyroxine binding in nephrosis (abstract). J. Clin. Invest., 1956, 35, 730.

10. Robbins, J., and Rall, J. E., Thyroxine-binding capacity of serum in normal man. J. Clin. Invest., 1955, 34, 1324.

11. Robbins, J., Reverse-flow zone electrophoresis. A method for determining the thyroxine-binding capacity of serum proteins. Arch. Biochem. \& Biophys., 1956, 63, 461.

12. Barker, S. B., Determination of protein-bound iodine. J. Biol. Chem., 1948, 173, 715.

13. Zak, B., Willard, H. H., Myers, G. B., and Boyle,
A. J., Chloric acid method for determination of protein-bound iodine. Anal. Chem., 1952, 24, 1345.

14. Robbins, J., Petermann, M. L., and Rall, J. E., Electrophoresis of the thyroxine-binding protein of serum at $\mathrm{pH}$ 4.5. J. Biol. Chem., 1955, 212, 403.

15. Petermann, M. L., Robbins, J., and Hamilton, M. G., Sedimentation of the thyroxine-binding protein of serum in the partition cell. J. Biol. Chem., 1954, 208, 369.

16. Robbins, J., and Rall, J. E., The interaction of thyroid hormones and protein in biological fluids in Recent Progress in Hormone Research. New York, Academic Press Inc., 1957, vol. 13.

17. Robbins, J., Thyroglobulin in serum after $\mathrm{I}^{121}$ therapy. I. Salting out. J. Biol. Chem., 1954, 208, 377.

18. Gordon, A. H., Gross, J., O'Connor, D., and PittRivers, R., Nature of the circulating thyroid hormone-plasma protein complex. Nature, 1952, 169, 19.

19. Larson, F., Deiss, W. P., and Albright, E. C., Localization of protein-bound radioactive iodine by filter paper electrophoresis. Science, 1952, 115, 626.

20. Robbins, J., and Rall, J. E., Zone electrophoresis in filter paper of serum $\mathrm{I}^{131}$ after radioiodide administration. Proc. Soc. Exper. Biol. \& Med., 1952, 81, 530.

21. Bücher, T., Matzelt, D., and Pette, D., Papierelektropherogramm der Eiweisskörper des Liquor cerebrospinalis. Naturwiss, 1952, 39, 114.

22. Fisk, A. A., Chanutin, A., and Klingman, W. O., Observations on a rapidly migrating electrophoretic component of cerebrospinal fluid. Prcc. Soc. Exper. Biol. \& Med., 1951, 78, 1.

23. Alpers, J. B., and Rall, J. E., The metabolism of iodine in cerebrospinal fluid. J. Clin. Endocrinol. \& Metab., 1955, 15, 1482.

24. Brown, R. K., Baker, W. H., Peterkofsky, A., and Kauffman, D. L., Crystallization and properties of a glycoprotein isolated from human plasma. $\mathrm{J}$. Am. Chem. Soc., 1954, 76, 4244.

25. Peterkofsky, A., Levine, L., and Brown, R. K., Quantitative estimation of antigens by complement fixation. Studies on the heat-labile alpha-2 glycoprotein. J. Immunol., 1956, 76, 237.

26. Hoch, H., and Chanutin, A., Electrophoretic studies on fast moving components of human serum. J. Biol. Chem., 1953, 200, 241. 